\title{
Sciendo
}

DOI: $10.2478 / \mathrm{aa}-2020-0009$

\section{Reflections on happiness and a happy life}

Viera Jakubovská, Jana Waldnerová

Viera Jakubovská teaches at the Department of Philosophy of Constantine the Philosopher University in Nitra, Slovakia. In her research, she deals with the history of philosophy, aesthetic, ethical and artistic problems of the body and corporeality as well as with philosophy of culture. She has published several books, including Exploring problems of human body and corporeality (2012 in collaboration), Philosophical and aesthetic reflexions of profane and sacral (2013), Metamorphoses of the body in philosophic, artistic-scholarly discourses (2017), Reflexions of the body and corporeality in the context of contemporary art and digital media (2018 in collaboration).

Jana Waldnerová teaches at the Department of English and American Studies at Constantine the Philosopher University in Nitra, Slovakia. In her research she deals with contemporary Anglophone literature, fictional worlds and humour. She is an author and co-author of several books dealing with fictional worlds, humour and corporeality in contemporary art.

\begin{abstract}
:
The main objective of the following text is to focus on and exemplify the basic axioms of theories of happiness that come from historical and philosophical tradition and are still, at least in some cases, relevant nowadays. As philosophers claim, the longing for happiness is a naturally human desire that has taken various forms in their thinking: happiness was connected with beatitude (Aristotle), with self-preservation (Spinoza), social helpfulness (Hume), living in the present moment without expostulations or false illusions (ComteSponville), and others. The desire for happiness means the main aim of a human life drives particular life goals and the values of individuals. Concepts of happiness have accrued in diachronic and synchronic cross-sections. The Aristotelian/Spinozan conception or Kantian, modern and postmodern traditions formed in a diachronic cross-section. Those that accrued in a synchronic cross-section segregated themselves on the basis of an individual's spiritual and bodily aspect. Spiritual happiness (spiritual bliss, and inner equilibrium, ataraxis) was

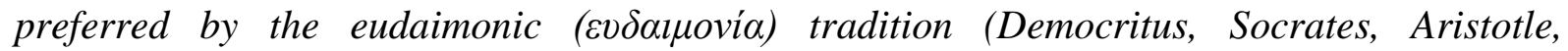
Hellenism, French materialism and others); bodily pleasures were accentuated by the hedonistic traditions (Lipovetsky, Bauman, Keller). Some conceptions examined the problem of happiness through the optics of society and the individual, stressing general goodness and helpfulness (Plato, Aristotle, Kant); or personal goodness, pleasure and benefit - the contemporary hedonistic concepts (Lipovetsky, Maffesoli, Comte-Sponville) All these conceptions of happiness are united by the common desire of people to live happily; however, their means and ways to reach such a goal are different.
\end{abstract}

"Happiness is the only thing that matters." (Comte-Sponville, 2018, p. 50) 


\section{Introduction}

Happiness, as a state of psychological and physical satisfaction or delight, occupies an important place in human life because every person longs to lead a happy life. The problem starts with our search for the meaning of the notion when we try to find out how we can become happy, how we should live our life happily (Liashchynskaya, Jakubovska, 2017).

In recent years this problem has become resonant in philosophy, sociology, political science and ethics as well as in everyday life. This is connected with our contemporary, hyper-consumer society that is satisfying our primary and secondary needs but does not make all of us happy (Kahneman, 1999). The problem of happiness as was examined in the history of philosophy from the antique period (in the diachronic cross-section), and also within the frame of moral philosophy (in the synchronic cross-section), was connected with other issues. The first of them was the problem of virtue or goodness, which we regard as an important issue of moral philosophy with its history and evolution (Socrates, Plato, Aristotle, Kant and others). The second problem was the relation between an objective law/imperative and subjective action/desire. The third problem was the relation between the whole and its part (the whole means the moral orientation of society and personal happiness as its part). Thinking about happiness uncovers various problems. The basic one is that although at the centre of attention of every person is happiness/a happy life, most of us do not know what exactly the meaning of them is. Happiness is connected with notions like fulfilment or personal self-fulfilment, quality of life, and bliss (Fula, 2004, p. 110) due to its semantic multi-valuedness, which is similar to other philosophical notions like goodness, beauty, fairness or freedom. In his essay on happiness (1990), W. Tatarkiewicz distinguishes four basic senses of this notion: 1 . happiness as an ominously positive experience; 2 . happiness as a state of satisfaction with one's own life that is apprehended as a wholeness; 3. happiness as a success, good fate, or fortune; 4. happiness as eudaimonia, i.e. as possession of the greatest goodness available to man. (Tatarkiewicz, 1990, p. 111). Distinguishing between the second and fourth definition of the notion (hedonic happiness and eudaimonia) is the key aspect of this text. Its importance is not only historical. We can apply it also in our contemporary thinking about happiness.

\section{Historical-philosophical excursus}

In the history of moral philosophy/ethics, exploration of human virtues was viewed with high importance. The first complex theory was created in the antique period by Plato, Aristotle and later, by their successors T. Aquinas, B. Spinoza, D. Hume, I. Kant, M. Scheler, N. Hartman 
and others. Development of several theories of happiness can be found in texts such as The Nicomachean Ethics (Aristotle), Letter to Menoeceus (Epicurus), On Duties (Cicero), Ethics (Spinoza), An Enquiry Concerning the Principles of Morals (D. Hume), Critique of Pure Reason (I. Kant), On Shame (M. Scheler), Happiness and Benevolence (Spaemann), Happiness, an essay (R. Misrahi), A Short Treatise on the Great Virtues (A. ComteSponville), The Society of Eternal Youth (Keller), and others.

In the antique period we can identify the double idea of happiness that was created by Aristotle, the most important representative of the antique theories on happiness. The theory speaks about double happiness - a life oriented towards contemplation (1) and a virtuous everyday life (2). According to Aristotle, man can achieve happiness in two ways. The first is contemplation; the second is the attempt to practise virtues in life in the process of coexistence with other people (in polis). The second case is a happy practical life (bios praktikos) - happiness reached via the rationally driven activities and passions of man. In the first case, happiness is connected with a philosopher's life (the one who contemplates truth). In the classical interpretation of happiness (Aristotle was its important representative), the meaning of happiness goes beyond delight. Although delight is one aspect of happiness, it can't ever be any reason for rational action. As Aristotle wrote in The Nicomachean Ethics, people who believe that happiness consists of delight behave like slaves, satisfy themselves with sensuality (animality), which is similar to animals. They do not care about the reason that makes them god-like (Aristoteles, 1996).

Epicurus followed Aristotle in his theorizing on happiness; however, he favoured Aristotle's second concept. It might seem that his theory is radically different from Aristotle's since he preferred hedonism, which is frequently understood, especially by laypeople, as endless satisfying of primary needs. Those who are introduced to Epicurus's theory know that when speaking about happiness he meant a life without fear. Life without fear, especially fear of the unknown, became the leitmotif of his philosophy. Epicurus thought that man should try to achieve spiritual peace because those who live in fear are not able to be happy. Knowledge leads to happiness. The clever man should avoid confrontation, should not lose his inner attitude; he finds happiness in everything that does not harm him. Joy is key to a happy life, even if we cannot always avoid suffering. Being clever means that one can bear sad days knowing that the pain is only temporary and a new joy will come later. The Epicurean idea of happiness is connected with other ideas: the clever man should not live in abundance, the happy man is the one whose needs are the smallest and who can enjoy them nevertheless (Epicurus, 2007, p. 337). 
Epicurean ethics aimed at achieving happiness and bliss with virtue as its necessary condition. In this theory, virtue becomes a means. Man chooses moral values but not happiness. He is naturally carried towards it. Selection of moral values is the result of free will. The choice can be either positive - we choose the beneficial (physical health, peace of mind) or negative (we refuse physical pain or spiritual discomfort). Epicurus rejected the idea of predestination of action; he claimed that the acts of every man should be independent and free, that a man should control his own life which is possible only if he understands human life (Predanocyová, 2013). Moral action is realized on grounds of acquired knowledge, experience and upbringing. The key notion of this hedonistic ethics is bliss/delight, which means the final goal as well as initial and inherent goodness a man necessarily tries to achieve (Epicurus, 2007, p. 128-131). Human action is oriented towards the satisfaction of desires via delights, that is how we reach bliss during our life, and the bliss is the outcome of knowledge. Only the right knowledge leads to a good, peaceful and happy life. The right knowledge is perceived as understanding nature and man; it also means the development of understanding of the causality of phenomena around us; it becomes a means of spiritual peace and life without trauma or fear. A man does not have to satisfy all his cravings to reach equilibrium necessary for a happy life. He has to decide which of his desires are beneficial for him and which are not. And Epicurus goes further in his contemplations when he explains that absence of craving is the criterion of ataraxis (spiritual equilibrium) and also of the aponia (a state without any pain).

Representatives of the Aristotelian/Spinozan tradition (Epicurus also belongs there) perceived measures of happiness as an expression of the most inner human desire as well as the most important aim controlling human action, when happiness was interrelated with a virtuous life. Aristotle's theory of virtue is quite often compared to Spinoza's theory of ethics due to their similar bases, although their indicators of happiness are different. In Aristotle, it is bliss while in Spinoza self-preservation. The pursuit of goodness and happiness in life means the development of individuals in Spinoza (Spinoza, 1977, p. 234). Only common sense can lead to the desired state - Spinoza agrees with Aristotle on this. He understands virtue as man's ability to cope with his affections - to learn their sources, apprehend their attributes as products of natural exigence, and to place them under rational control. Both the aforementioned philosophers also believe that pursuit of the highest goodness corresponds with man's ability to rationalize his passions. However, there is a principal difference between them because according to Aristotle, the natural desire for a happy life spurs man to become 
virtuous and the good (or bliss) is a reward for a virtuous life. In Spinoza, the virtue itself the taming of passions by the mind - was the good (bliss): virtue becomes a reward in itself.

The German philosopher Immanuel Kant came up with a different theory of happiness. In his examination of happiness, he accentuated that not every individual's actions correspond with generally respected behaviour. He did not deny the importance of human craving for happiness but did not regard it as right or proper to base morality on so subjective and emotionally burdened a notion as happiness (Kant, 1996, pp. 45-47). He pointed to the impossibility of defining happiness in the sense of a universal principle. Ideas about happiness are various, and that is why it is impossible to follow simultaneously common and individual happiness. This corresponded with the classical Aristotelian/Spinozan tradition of happiness that emphasized the relationship between the good and happiness and also dealt with the area where we can expect our happy life to be realized - during our life or after it, after death (T. Aquinas). The problem between the part and the whole (individual - society) in their relation to happiness was secondary in this theory without objective and universal rules of behaviour leading to happiness. If we thought about it, we could see that it would not be a simple task to identify a concrete core of happiness from an objective perspective, no matter if we take into account the practical-normative context of the period. According to Kant, to achieve happiness, we have to behave morally. Happiness means a good and successful life. If we try to connect it with pleasure as its determining criterion, then we have to realize the existence of different pleasures: the right/ noble and delusional/degrading. Happiness and pleasure do not have any measure other than delight itself, and this measure is empiric and posterior. Kant also believed that longing for happiness could sometimes even endanger a person's uprightness - self-love can devalue the moral life of a person (Kant, 1996). Within the history of philosophy or moral philosophy, the problem of happiness was quite problematized due to the question whether people can have a happy life while they are alive or only after their death and also if such a life is possible or whether there exists only some utopian ideal (Renaissance utopia, existentialism, eschatological concepts) and real life can't satisfy our desire for happiness.

\section{Reflection on the contemporary situation}

Under the influence of liberalism, the subjectivist concepts of happiness that perceive happiness as a sensual experience - to feel happy - prevail in modern and postmodern theories on happiness. 
At first, there was the existentialist tradition (with human existence at the centre and a dominating certitude that the human condition should be reflected rather through the notion of the tragic than through the primacy of the craving for happiness. In Sartre's theory, this stemmed from the condemnation of freedom (Sartre, 1997), through happiness that means satisfying urges [psychological reductionism and hedonistic conceptions of Lipovetsky and Maffesoli] to M. Seligman's positive psychology (the concept of personal well-being).

In the second half of the 20th century, A. Comte-Sponville (A Short Treatise on the Great Virtues, 2018), a contemporary French philosopher, developed his theory of the happy life in symbiosis with the notion of hopelessness, relating it to stoicism (and the spiritual peace reached by control of the passions) and Epicurus's idea of wisdom. He expresses that when people are prisoners of their dreams about a better future, of false illusions, disappointments and reprimands from the past, they do not see the value of real life (which they live here and now), and they cannot be happy. If they want to live happily, they have to live in the present time, without exaggerated and unreal illusions and make a realistic judgment regarding their possibilities because only knowing the cause of sorrow opens the way towards happiness (p. 218).

The hyper-consumer era behaves according to Comte-Sponville's words thusly: people live their lives in the present. Another French philosopher and sociologist, G. Lipovetsky, supports this idea in his reflection on the contemporary, hyper-consumerist times. In his opinion, human hopes that were connected with a historical future in the past are replaced by life in the present, political fights or hedonism. Nowadays, even neo-nationalistic passions are pushed back due to a feverish desire for comfort and revolutionary tendencies shifted aside by leisure time. A better life is anchored in the new cult of constant improvement of living conditions, which became a mass passion and also the highest aim of contemporary democratic societies (Lipovetsky, 2007, p. 3). The transformations in the everyday market supply, and the practices and psychological influences on consumers that started in the last two decades of the 20th century had such an effect that our contemporary consumer society was redefined as hyper-consumerist. This kind of society is characterized by variety and creativity, in which the criterion of company compatibility is not only the quality of products but also time, innovation, distribution, marketing and others. The supply-side economy changed to the on-demand economy, and product-oriented companies changed to market and consumer-oriented companies. The spirit of consumption gradually infiltrated into all areas of public and private life, into families, religion, policy, culture, into leisure time, which has been extending more and more, and our investments in it have been growing proportionally. 
Games, entertainment, challenges and longing for new experiences have become common elements of human life. Nowadays, people want to have everything and as soon as possible (immediately and without any effort if possible. The contemporary world suffers from a shopping epidemic. Society feeds unceasing hunger for news, lives in abundance and waste, and lifestyle has become a private affair (Jakubovská, 2014). The wealth that people desire nowadays does not only mean its traditional financial form but also psychological comfort, inner harmony and personal self-fulfilment. The IT revolution created the conditions for a new kind of society - the society of networks and information capitalism. However, these highly technological societies focus on various eastern philosophies, spirituality, spiritual transformations and mental well-being (Jakubovská, 2016, p. 920), consequently, man is reevaluating the existential and spiritual dimension of existence. On the one hand, the hyperconsumer society celebrates the ideal of abundance, harmony and inner balance and at the same time it is uncontrollable, it creates extremes, chaos and antithesis. Changes in values and approaches are taking their course, and quality of life, spirituality and self-reflection have preference over maintenance and supply. In his text, G. Lipovetsky explains that to live freely without any limits is the highest social and cultural factum of our era and also the most undeniable right in the eyes of our contemporaries (Lipovetsky, 1998, pp. 11-12).

The consumer society reached the third phase of its evolution at the beginning of the 1970s. The emotional consumption which became emphasized is primarily aimed at visions, concepts and lifestyles, and the product itself has only secondary importance. Consequently, people frequently buy based on brand and not product. This is connected with the narcissistic pleasure in being different from the ordinary or average, when people create a positive image to confirm their own value of themselves and reach inner satisfaction (Jakubovská, et al., 2018, p. 57). The glorification of brands has its roots in the aforementioned narcissistic desire to experience an inner feeling of one's own extraordinariness, feeling that a person is better compared to others, different from those around (Lipovetsky, 2007, p. 55). Nowadays, consumption has become a tool of a personal ascendance over everydayness, a manner of extending autonomy that liberates an individual from the confinements of a group or of nature. Hedonism can be identified in fashion, luxury, eating as well as in the prodigal way of life. Under the authority of fashion, people observe and evaluate their appearance and this incites a critical view, personal involvement and aesthetic self-observation (Kubatova, 2010, p. 201). In Lipovetsky's work on happiness, subjectivism, hedonism and relativism dominate, and the prioritization of the part over the whole, of the individual over society and especially the life here and now are emphasized. 
A new scientific discipline - positive psychology (the psychology of happiness) promoted by M. Seligman was formed in the 1970s owing to great changes in the behaviour of postmodern man, pressure on work output and the effort to support one's family (Seligman, 2017). Seligman himself examined the influence of psychological factors on maintaining personal health and prophylaxis. In his opinion, the human ability to be happy is mostly based on genetics, as it is an outcome of one's own will. Its dependence on external conditions is very small. The only way to happiness, in his opinion, is to change one's thinking and one's feelings because the feeling of happiness is a provision leading to success in school, work and life too.

A. H. Maslow, American psychologist, psychiatrist and philosopher and the founder of humanistic psychology dealt with the hierarchy of human needs, motivation and personal selffulfilment. He assembled the hierarchy of human needs (Maslow's hierarchy) based on the contemporary context. At the bottom there are physiological needs, then safety needs, followed by belongingness and love needs, then esteem needs, and finally self-actualization needs in the top position. Seligman's conception of a happy life corresponds with the social context of the second half of the 20th century and does not contain any need to secure certainty or safety (Seligman, 2017, p. 220). The author builds his conclusions on the characteristics of a consumer society that is based on the market economy, with risks and incertitude intruding into the lives of individuals who cease thinking about the need to have a constant income or a guaranteed life-long career. On the contrary, to feel happy also in an aleatory and risky environment becomes most natural for them.

Seligman (2017) explains the importance of the five basic elements that he regards as supreme for our feeling of happiness: positive emotions, (the ability to be constantly optimistic and to approach one's past, present and future in a constructive manner, which increases our creativity, simplifies the use of opportunities and helps to avoid depression from failure. It is important to change every activity, especially a boring one, to something challenging and pleasant; to have positive relationships with others (to grasp that we are not alone and other people are here to help us in our difficult times); to feel the purpose of one's life (the ability to answer questions why the individual is here, what is s/he doing and why is s/he doing it); and to have realistic goals and achieve them (to have results). Happy people work under any conditions; they can better cope with changes and are less predisposed to burnout. They are more autonomous, flexible and challenge themselves with more ambitious goals. Seligman believed that the feeling of happiness can be learnt. Between 2008 and 2017, the psychology of happiness was introduced into primary, secondary schools and universities 
in the USA, UK, Canada, China, India and the United Arab Emirates. Positive psychology designed formulae for happiness that people can learn because according to it, every individual is responsible for his/her happiness.

At the beginning of the 21 st century, happiness was even measured within the scope of positive psychology - so-called rough national happiness regarded as the real indicator of social and political progress. Happiness became measurable, evaluated and compared like production and consumption - when it is growing then also the personal fulfilment of people is growing as well as the return on investments regardless of the conditions in society.

Jan Keller, the Czech sociologist and environmentalist also deals with happiness and the happy life in a hyper-consumerist society that places such high demands on each individual (2019). He asks how people can achieve happiness that turns into a driving force and leads to self-development, and also what contemporary people can do for themselves to become successful in developing their creativity, in fulfilling their plans and desires. He examines happiness as a value in society in which youth, success and creativity are regarded as the highest values since these are connected with optimism and a positive lifestyle. He agrees with Lipovetsky that in the time of commercial stagnation, economic growth is replaced by psychological development (1998). Keller writes that one who is not happy is ill in some way, regardless of the reason. Only content people can get maximal value from their capital (themselves). In his thinking, he goes further and claims that inequality of income and concentration of capital has a positive impact on the feeling of happiness when existing disparity challenges hopes in the poor that they will also achieve similar success one day in the future as the rich enjoy in the present. Their hope in future happiness becomes a strong motivation. The individual psychological state is very important for happiness, but there is still a question if this motivation is not a way to the burnout, workaholism and depression that we hear about so frequently nowadays.

\section{Conclusion}

Despite different principles and dissimilar social-historic contexts, the concepts that are introduced in this text are connected by an assertion that what should be (what is required) is not strictly separated from the existing really (from factual human existence). As Smrekova said, people do not try to recognize what is morally good to incorporate it into their lives and behaviour regardless of its consequences and the effects of such a choice on the quality of their individual and social life. On the contrary, people crave to improve their lives, to have success, to lead a good life or to be happy (2003). From the previous statement, we can 
conclude that happiness is a final goal of human life, and it corresponds with a moral life and experience of the subject on the one hand and with the world where s/he lives on the other. Health and living standards, the state in which the individual is, friends and other attributes decide on one's happiness as we can read in Aristotle and Kant: happiness is the state of an intelligent being in the world, where one is successfully fulfilling one's desires and will do so during one's whole existence (Kant, 1996). Happiness is not a matter of the individual because man is a social being who experiences various relationships - with other people or with nature, and these relationships change due to the effects of time and the individual psychological-social evolution in which people live. We suppose that most of us can agree with this, and that is why we should understand that to live a good life means a disposition to act in a certain manner. If people want to be happy, they should act reasonably and choose realistic goals. In case the conditions they calculated on change, they should reevaluate those goals. We should understand that dearth just like abundance destroys harmony and equilibrium in our lives and therefore moderation is the right principle for any activity, including living our lives.

\section{Works cited:}

Aristoteles. 1996. Etika Nikomachova. Praha : Petr Rezek

Comte-Sponville, A. 2018. Štastie bez ilúzií. Bratislava: Eterna Press.

Epikuros. 1989. O št’astnom živote. Bratislava : Pravda.

"Epikuros pozdravuje Herodota." In Diogenes Laertios: Životopisy slávnych filozofov. Bratislava, Vydavatel'stvo spolok slovenských filozofov, 2007, p. 337.

"Epikuros pozdravuje Menoikea." In Diogenes Laertios: Životopisy slávnych filozofov. Bratislava, Vydavatel'stvo spolok slovenských filozofov, 2007, pp. 128-131.

Fula, M. 2004. “Téma št’astia v morálnej filozofii.“ In FILOZOFIA. Vol. 59. No. 2. pp. 110123.

Haidt, J. 2014. Hypotéza štěstí: hledání modernich pravd ve staré moudrosti. Praha : Dokořán, s.r.o.

Jakubovská, V. 2014. "Postmodern Modifications of the Human Body's Imaging in the Slovak Cultural Tradition." In: International multidisciplinary Scientific Conferences on Social Sciences and Arts SGEM. Albena : Bulgarian Academy of Sciences. pp. 815-822.

Jakubovská, V. 2016. "Return to body and corporeality through phenomenology of perception." In: SGEM Proceedings from 3rd International Multidisciplinary Scientific Conference on Social Sciences and Arts. Sofia : STEF 92 Technology. pp. 917-924.

Jakubovská, V. et al. 2018. Reflexia tela a telesnosti v kontexte súčasného umenia a digitálnych médií. Boskovice : František Šalé - Albert.

Kahneman, D. 1999. "Objective happiness." In D. Kahneman, E. Diener \& N. Schwarz (Eds.), Well-being: The foundations of hedonic psychology. pp. 3-25.

Kant, I.1996. Kritika praktického rozumu. Praha : Svoboda.

Keller, J. 2019. Společnost věčného mládí. Praha : Slon.

Kubatova, H. 2010. Sociologie životního způsobu. Praha : Grada Publishing, a.s. Liashchynskaya, I., Jakubovská, V. 2017. "Humanities Education As Place for CulturalHistorical Memory“, In: Konštantínove listy. Vol. 10, No. 2. pp. 191-203. 
Lipovetsky, G. 2007. Paradoxní štěstí : esej o hyperkonzumní společnosti. Praha : Prostor. Lipovetsky, G. 1998. Éra prázdnoty : Úvahy o současném individualismu. Praha : Prostor. Predanocyová, L.2013. Epikurov etický projekt. Nitra : Univerzita Konštantína Filozofa Sartre, J.P. 1997. Existencializmus je humanizmus. Bratislava : Asociácia organizácií spisovatel'ov Slovenska.

Seligman, M. E. P. 2017. Authentic Happiness: Using the New Positive Psychology to Realize Your Potential for Lasting Fulfillment. New York : Free Press.

Smreková, D. 2003. Dobro a cnost' : etická tradícia a súčasnost'. Bratislava : Iris.

Spinoza, B. 1977. Etika. Praha : Svoboda.

Tatarkiewicz, W. 1973. O št'astí. Bratislava : Smena.

Viera Jakubovská

Department od Philosophy

Faculty of Arts

Constantine the Philosopher University

Nitra Slovakia

vjakubovska@ukf.sk

Jana Waldnerová

Department of English and American Studies

Faculty of Arts

Constantine the Philosopher University

Nitra Slovakia

jwaldnerova@ukf.sk 